\title{
Children's Right to Participate and Their Developing Role in Finnish Proceedings
}

\author{
Hannele Tolonen
}

\section{Introduction}

\subsection{On Participation}

Children's right to participate is a wide concept. Participation can take place in many contexts, from collective participation in community decision-making to individual participation in court and administrative proceedings, as well as in everyday situations in education and health care. ${ }^{1}$

Since 1995, Finnish children have had a constitutional right to influence matters that affect them, in accordance to their development. ${ }^{2}$ Long before that, provisions on children's participation have existed in many fields of legislation. After turning 15 years, children have independent procedural participatory rights (puhevalta) in court proceedings that concern their person, along with their representatives. Since the 1970s, provisions on taking into account children's opinion have become common in many areas, for example, in legislation on parental responsibility and child protection measures.

Children's opportunities to participate in judicial and administrative proceedings have been emphasised in the United Nations Convention on the Rights of the Child (CRC, article 12), which has been implemented in the Finnish legislation since 1991. In the recent years, providing children opportunities for participation has been widely discussed in Finland and emphasised in various fields. According to the Youth Act 1285/2016 (nuorisolaki), the aim now applies well into adulthood.

Despite the strong institutional support for children's participation, there are also concerns on strengthening children's role in decision-making. One of the main questions is whether the child benefits from the involvement or whether it will be harmful, for example straining their family relations, when

1 On the aspects of the concept, see for example UN Committee on the Rights of the Child, General comment No. 12 (2009): The right of the child to be heard (20 July 2009) CRC/C/GC/12 para 32.

2 Suomen perustuslaki (731/1999) section 6, subsection 3. 
the matter concerns them. ${ }^{3}$ On the other hand, the UNCommittee on the Rights of the Child has criticised Finland for not sufficiently ensuring children's hearing, mentioning parental responsibility proceedings as an example. ${ }^{4}$

When children's family members are involved in legal proceedings that concern children, questions arise on children's representation when the interests of children and adults may conflict. In handling of these conflicts, a sharp division has emerged between the fields of Finnish family legislation. This became evident when Finland ratified the European Convention on the Exercise of Children's Rights (CECR) in 2011. Some of its provisions discuss special representation for children in case of a conflict of interests between the child and the holders of parental responsibility. ${ }^{5}$ In Finland, the CECR is only applied in the fields of child protection, paternity and adoption, ${ }^{6}$ but not in proceedings on parental responsibility and contact, for example. In the recent case law on the right to family life (the European Convention on Human Rights (ECHR) article 8), the European Court of Human Rights (ECtHR) has taken a stronger stand on the standards of children's participation in parental responsibility proceedings, underlining for example the principles that are expressed in the CECR. ${ }^{7}$

\subsection{The Scope and Material}

In this work, the roots, the effects, and the limitations to children's right to participate are discussed in the Finnish context. Where have we now arrived, what are the main trends of development and how does the current system of children's procedural participation compare to the developing international standards?

I begin with a concise introduction to the constitutional framework and children's collective and individual participatory rights in light of the Finnish

3 On possible risks see, for example, Eva Gottberg, 'Lapsen subjektiudesta ja osallisuudesta huoltokysymyksissä ja lastensuojelussa' (2008) 3 Defensor Legis 319, 321. On international discussion see for example Patrick Parkinson and Judy Cashmore, The Voice of a Child in Family Law Disputes (Oxford University Press 2008) 14; Jill Duerr Berrick and others, 'International Perspectives on Child-responsive Courts' (2018) 26 Int J of Children's Rights 251, 254.

4 UN Committee on the Rights of the Child, Concluding observations: Finland (3 August 2011) CRC/C/FIN/CO/4 paras 29-30. The word used in the text is custody.

5 If internal law precludes the holders of parental responsibilities from representing the child because of such conflict of interests, judicial authorities shall have a power to appoint a special representative (article 9.1) and the child shall have a right to apply for one (article 4.1).

6 Tasavallan presidentin asetus lasten oikeuksien käyttöä koskevan eurooppalaisen yleissopimuksen voimaansaattamisesta sekä yleissopimuksen lainsäädännön alaan kuuluvien määräysten voimaansaattamisesta annetun lain voimaantulosta (13/2011) section 3 .

7 The case law will be discussed later. 
legislation. Then, children's rights to participate in court proceedings are more closely examined, analysing in more detail some aspects of their procedural participation. The focus here is in proceedings on parental responsibility and child protection, where discussion is abundant and legislative measures are developing. Adoption, paternity, immigration and criminal proceedings are also mentioned where relevant.

The main sources are legislation, preparatory works, case law of the two supreme courts and legal doctrine, as well as material on international human rights conventions. In addition to the case law of ECtHR, references are made to the discussion on the CRC and the CECR. ${ }^{8}$ The focus is in the recent developments, but to illustrate the background, some examples are given on the legislative history.

\section{Children, Constitution and Participatory Rights}

\subsection{On the Constitutional Framework}

The Constitution of Finland 731/1999 (Suomen perustuslaki) came to force in 200o. A domestic turning point in the development of fundamental rights has been set a few years before, when the previous Constitution was modified (969/1995) after Finland joined the ECHR. ${ }^{9}$ According to the preparatory works, the constitutional rights and the international human rights would be brought closer together, and the need to harmonise their interpretations would become more pronounced. ${ }^{10}$ The human rights provisions are considered to set a minimum standard of protection, which may be surpassed in the domestic constitutional norms. However, it has been pointed out that the courts give considerable weight to the case law of ECtHR in their interpretations. ${ }^{11}$

8 Children's right to express their views and have them taken into consideration is also acknowledged in the Charter of Fundamental Rights of the European Union, article 24(1). The charter will not be discussed in this work.

9 See Pekka Länsineva, 'Perusoikeusliike' in Tatu Hyttinen and Katja Weckström (eds), Turun yliopiston oikeustieteellinen tiedekunta 50 vuotta (Turun yliopisto, oikeustieteellinen tiedekunta 2011) 339, 342.

10 Perustuslakivaliokunnan mietintö n:o 25 hallituksen esityksestä perustuslakien perusoikeussäännösten muuttamisesta (PeVM 25/1994) 5 .

11 Tuomas Ojanen and Martin Scheinin, 'Kansainväliset ihmisoikeussopimukset ja Suomen perusoikeusjärjestelmä' in Pekka Hallberg and others, Perusoikeudet (WSOYpro 2011) 191-194. The writers call for a stronger role to the Constitution. On criticism of a strong fundamental right approach see Markku Helin, 'Perusoikeuksilla argumentoinnista' in Tero Iire (ed), Varallisuus, vakuudet ja velkojat: Juhlajulkaisu Jarmo Tuomisto 1952 - 9/6-1912 (Turun yliopisto, oikeustieteellinen tiedekunta 2012) 11. 
Finnish courts may give primacy to the Constitution if there is an evident conflict with an Act. ${ }^{12}$ Primarily, the constitutionality of legislative proposals is supervised by the Constitutional Law Committee of the Parliament (perustuslakivaliokunta). ${ }^{13}$ In its supervisory role, the Constitutional Law Committee also assesses how the proposals relate to international human rights treaties, such as the ECHR and - as in questions on children's participation - the CRC. ${ }^{14}$

From the historical perspective, children have not always been considered holders of fundamental rights as they clearly are today. ${ }^{15}$ In the constitutional reform, children's constitutional rights were acknowledged in a specific provision. Firstly, children shall be treated equally and as individuals. Secondly, their right to participation is acknowledged: children shall be allowed to influence matters that concern them in accordance to their level of development. ${ }^{16}$ The provision was influenced by the $\mathrm{CRC}$, which is mentioned in the preparatory works. ${ }^{17}$

According to the government's proposition, children have fundamental rights, but in practical situations, the central question may be who exercises these rights. ${ }^{18}$ This stance puts the focus on formal participation by children's representatives - generally parents - and emphasises the material aspects of decision-making instead of children's procedural participation. Nevertheless, it has been pointed out that restricting children's autonomy calls for sufficiently

12 Constitution, section 106. An unofficial translation is available at $<$ https://www.finlex.fi/ en/laki/kaannokset/1999/en19990731_20111112.pdf $\geq$ accessed 11 February 2019. On Supreme Court case law see, for example, KKO 2012:11 and KKO 2015:14, where procedural rights were discussed in light of ECtHR case law.

13 If the committee has ruled out a conflict in a certain specific question, the chance of a court finding otherwise has been considered narrow. Veli-Pekka Viljanen, 'Perusoikeuksien merkitys lainsäädäntötyössä' in Pekka Hallberg and others, Perusoikeudet (WSOYpro 2011) $847-848$.

14 See Perustuslakivaliokunnan lausunto hallituksen esityksestä lastensuojelulaiksi ja eräiksi siihen liittyviksi laeiksi (PeVL 58/2006), where the Constitution, ECtHR case law and CRC were discussed in assessing the proposition for the Child Welfare Act 417/2007 (lastensuojelulaki).

15 On the discussion in the 1970 and 1980s, see Liisa Nieminen, Lasten perusoikeudet (Lakimiesliiton kustannus 1990) 7 .

16 Section 6, subsection 3. Originally, Suomen Hallitusmuoto (969/1995) section 5, subsection 3. The latter part of the provision was added during the parliamentary work. PeVM 25/1994 (n 10) 7 .

17 Hallituksen esitys eduskunnalle perustuslakien perusoikeussäännösten muuttamisesta (HE 309/1993) 45. See also Liisa Nieminen, Perus- ja ihmisoikeudet ja perhe (Talentum 2013) 338; Henna Pajulammi, Lapsi, oikeus ja osallisuus (Talentum 2014) 109-110. 
precise legislation ${ }^{19}$ and that the provision should be interpreted in the context of the specific situation at hand. ${ }^{20}$

A more general framework for procedural participation is also set in the Constitution. Guarantees of a fair trial are included in the provision on constitutional right to protection under the law (Section 21, oikeusturva). According to the preparatory works, the purpose is to guarantee the rights that are provided in ECHR article 6. ${ }^{21}$ According to ECtHR, mere formal rights are not enough. Instead, effective possibilities for participation have to be provided. ${ }^{22}$ In Blokhin v Russia (2016), the Grand Chamber concluded that the applicant a child - was not afforded a fair trial in child protection proceedings because of the lack of legal assistance in police hearings and not having a chance to ask questions from the witnesses. ${ }^{23}$

In the case law of ECtHR, requirements to procedural participation also stem from the right to respect for privacy and family life (article 8). In the Finnish Constitution, the concept of family life is not mentioned. According to the preparatory works, it is included in the right to privacy. ${ }^{24}$ It has been argued that the close connection to the conceptual framework of ECHR, article 8, underlines the importance of ECtHR case law in interpreting this section. ${ }^{25}$

In ECtHR case law on family proceedings that fall under article 8, the parents' sufficient involvement in the decision-making process has generally been required. ${ }^{26}$ In a parental responsibility case M. and. M. $v$ Croatia (2015), similar

19 Nieminen (n 17) 340.

$20 \quad$ Pajulammi (n 17) 110.

21 HE 309/1993 (n 17) 73. The provision of International Covenant on Civil and Political Rights, Article 14 Section 1 is also mentioned here.

22 On the case law see, for example, Robin C. A. White and Clare Ovey, Jacobs, White and Ovey: The European Convention on Human Rights (5th edn, Oxford University Press 2010) 255 and 26o; Matti Pellonpää and others, Euroopan ihmisoikeussopimus (6th edn, Alma Talent 2018) 332.

23 Blokhin v Russia App no 47152/o6 (ECtHR, 23 March 2016). The proceedings were interpreted to constitute criminal proceedings within the meaning of article 6 . Therefore, more far-reaching procedural guarantees were applied.

24 Constitution, section 10 and HE 309/1993 (n 17) 53. See also Nieminen (n 17) 43. The right to family life in the Finnish context is discussed in more detail by Sanna Koulu, 'Children's Right to Family Life in Finland: A Constitutional Right or a Side Effect of the "Normal Family"?' in Trude Haugli and others (eds), Children's Constitutional Rights in the Nordic Countries (Brill 2019) chapter 17.

25 Veli-Pekka Viljanen, 'Yksityiselämän suoja (PL 10 §)' in Pekka Hallberg and others, Perusoikeudet (WSOYpro 2011) 393.

26 On the case law see, for example, Päivi Hirvelä and Satu Heikkilä, Ihmisoikeudet: Käsikirja EIT:n oikeuskäytäntöön (2 edn, Alma Talent 2017) 766 (child protection) and 770 (parental responsibility). 
considerations were applied to a child who could express her views but had not been provided the opportunity to be heard. ECtHR found a breach of the child's article 8 rights, referring to CRC article 12 and the comments of the UN Committee on the Rights of the Child. ${ }^{27}$

\subsection{On Children's Collective Participation}

A distinction can be made between children's participation in individual cases and their more general collective participation in society. ${ }^{28}$ In collective participation, one can distinguish between political or democratic participation and participation in governance, which can further be divided to electoral and non-electoral mechanisms. ${ }^{29}$

Electoral mechanisms are not generally available to children in Finland. According to the Constitution, the right to vote applies to persons who have attained eighteen years of age. In the provision, national and municipal elections and referendums, as well as European Parliamentary elections are mentioned. ${ }^{30}$ In parish elections, children of 16 years may vote. ${ }^{31}$

According to the Constitution, the public authorities also have a more general duty to promote individual opportunities to participate in societal activities. No age limit is set here. ${ }^{32}$ It has been pointed out that there may be a lack of precise forms of collective participation that would accommodate the special needs of children. ${ }^{33}$ According to the legislation on communities, youth councils have to be appointed in communities in order to secure children's and

27 M. and M. $v$ Croatia App no 10161/13 (ECtHR, 3 September 2015) paras 181-187. A breach of article 3 was also found, because the allegations of ill treatment had not been effectively investigated (para 163). The cases mentioned in this section will be discussed later in more detail.

28 See, for instance, Niina Mäntylä, 'Lasten ja nuorten osallistumisen oikeudelliset ongelmat' in Niina Mäntylä (ed), Lapset ja nuoret yhteiskunnan toimijoina (Vaasan yliopiston julkaisuja 2011) 25. Available at <https://www.univaasa.fi/materiaali/pdf/isbn_978-952476-379-o.pdf $\geq$ accessed 11 February 2019.

29 On terminology, see Meda Couzens, 'Child Participation in Local Governance' in Martin D. Ruck, Michele Peterson-Badali and Michael Freeman (eds), Handbook on Children's Rights: Global and Multidisciplinary Perspectives (Routledge 2017) 516. In Mäntylä (n 28) 25, the term 'yleinen' (general) participation is used when discussing collective participation. See also Pajulammi (n 17) 340.

30 Constitution section 14 .

31 The provision is now in the Church Act 414/2014 (kirkkolaki) chapter 23 section 12 . The age limitation was lowered in 2009 (689/2008).

32 Constitution, section 14, subsection 4. See also HE 309/1993 (n 17) 62.

33 Mäntylä (n 28) 25; Pajulammi (n 17) 36o. 
young people's opportunities for participation. In the preparatory works, the Constitution and CRC were acknowledged. ${ }^{34}$

\subsection{On Children's Individual Participation}

Provisions on children's right to express their views and opinions in matters that concern them have become common in the Finnish legislation. Many of them have similarities to CRC, article 12, requiring that children's views be taken into account according to their age and maturity. ${ }^{35}$ Such provisions with no specific age limit are present in legislation on child protection, parental responsibility, social welfare, and early childhood education, among others. ${ }^{36}$ Holders of parental responsibility also have to take into account children's opinions and views when making decisions on children's personal matters. ${ }^{37}$

An example of a more age-determined approach is in the Aliens Act. Hearing a child is required if the child is at least 12 years old before a decision concerning the child is made by an authority. An exception can be made if hearing is manifestly unnecessary. Younger children may be heard if they are sufficiently mature for their views to be taken into account. ${ }^{38}$ In a recent case concerning international protection, where a 13-year-old had not been heard by the immigration authorities, the Supreme Administrative Court stated that the concept of 'manifestly unnecessary' (ilmeisen tarpeetonta) should be interpreted narrowly. The court stated that the obligation to hear the child should be assessed in light of CRC articles 12 and 3(1), discussing the comments of the Committee

34 Kuntalaki (410/2015) section 26. Hallituksen esitys eduskunnalle kuntalaiksi ja eräiksi siihen liittyviksi laeiksi (HE 268/2014) 24.

35 On recent discussion of legislation in light of the CRC, see also Merike Helander, 'Utvecklingsbehov i den finländska lagstiftningen om barn' (2018) 1 Nordisk Administrativt Tidsskrift 5, 8.

36 See also legislation on immigration integration (1386/2010) and international protection (746/2011).

37 Act on Child Custody and the Right of Access $361 / 1983$ (Laki lapsen huollosta ja tapaamisoikeudesta, Custody Act) section 4, subsection 2. An unofficial translation is found at <https://www.finlex.fi/en/laki/kaannokset/1983/en19830361> accessed 11 February 2019. In a recent legislative reform, a specific provision on the obligation to give information was added. Custody Act section 4 subsection 3 (190/2019). This Act enters into force on 1 December 2019. See also Hallituksen esitys eduskunnalle laiksi lapsen huollosta ja tapaamisoikeudesta annetun lain muuttamisesta ja eräiksi siihen liittyviksi laeiksi (HE 88/2018) 37 .

38 Ulkomaalaislaki (301/2004) section 6 subsection 2. An unofficial translation is available at <https://www.finlex.fi/en/laki/kaannokset/2004/en20040301_20101152.pdf> accessed 11 February 2019. 
on the Rights of the Child. The Constitution was also mentioned. The decision of the immigration authorities was overturned. ${ }^{39}$

In the field of family law, children have long been allowed independent veto powers in certain matters. Since the first Adoption Act (laki ottolapsista 208/ 1925), mature children have had a right to refuse adoption. According to the current provisions, consent of children over 12 years is required for adoption unless they are unable to express their opinion. Younger children may refuse if they are considered sufficiently mature. ${ }^{40}$

Children also have veto power when decisions on parental responsibility are enforced. Currently, the age limit is 12 . Also here, younger children may be able to refuse the enforcement if they are considered sufficiently mature. ${ }^{41}$ In a recent legislative reform, it was added that in assessing the effects of a refusal, the motivation and independence of the opinion are to be taken into account. ${ }^{42}$ In the case of $C$. $v$ Finland (2006), ECtHR criticised the Finnish Supreme Court for giving an impression that 12 and 14 year old children could determine the outcome of a parental responsibility case. ${ }^{43}$

The children's mother had deceased. The Supreme Court ordered parental responsibility to her partner instead of the children's father, stating that a differing decision could not be enforced because of the opposition from children in light of their ages. The children's opinions had been assessed by social authorities and experts. ${ }^{44}$

Legislation on health care also gives children wide rights to participate in decision-making on their treatment. No age limit is stated here, which allows room for individual considerations. Children's opinions on treatment measures have to be assessed if that is possible with regard to their age or level of development. Minor children have to be cared for in mutual understanding

\footnotetext{
39 KHO 2017:81.

40 Adoption Act 12/2012 (adoptiolaki) section 10.

41 Laki lapsen huoltoa ja tapaamisoikeutta koskevan päätöksen täytäntöönpanosta 619/ 1996, section 2 .

42 Laki lapsen huoltoa ja tapaamisoikeutta koskevan päätöksen täytäntöönpanosta (191/ 2019) section 2 subsection 2. See also HE 88/2018 (n 37) 67-68. A similar interpretation was suggested in the early literature. Matti Savolainen, Lapsen huolto ja tapaamisoikeus (Suomen Lakimiesliiton kustannus 1984) 98.

43 C. $v$ Finland App no 18249/o2 (ECtHR, 9 May 2006) para 58. A breach of the father's article 8 rights was found. On the case see also Jane Fortin, Children's Rights and the Developing Law (3rd edn, Cambridge University Press 2009) 299.

KKO 2001:110.
} 
with them if they are able to decide on the treatment in light to their age and development. Such children also have a right to forbid that information on their health is given to the guardian. ${ }^{45}$ Interpretations of these provisions have been critically discussed. Concerns have been voiced on giving young children rights to independent decision-making and privacy from parents. ${ }^{46}$ The discussion has moved between everyday practicalities - such as keeping appointments, if the parents cannot access the computer system on behalf of their children - and more serious matters, such as the parents' knowledge on treatment that is given to their children. ${ }^{47}$ When the public health care officials set an age limitation for an effective consent for a vaccination that was offered at schools, the parliamentary ombudsman criticised the interpretation for not sufficiently taking into account individual differences in development. ${ }^{48}$

Children's consent and refusal after a certain age is also given weight in some other personal matters. The name of a child may only be changed with his or her consent, if the child has reached the age of 12. Younger children's names cannot be changed against their opinion if the child is considered sufficiently mature. ${ }^{49}$ According to the legislation on freedom of religion, a child above 15 years may join or leave a religious community if the holders of parental responsibility give their consent. A lower age limitation is set to 12, after which age a child's consent is required for these changes. ${ }^{50}$

45 Act on the Status and Rights of Patients (laki potilaan asemasta ja oikeuksista 785/1992) section 7 ; section 9 subsection 2 . An unofficial translation is available at $<\mathrm{https} / / \mathrm{www}$.finlex.fi/en/laki/kaannokset/1992/en19920785_2012069o.pdf> accessed 11 February 2019.

46 See Kirsi Pollari and Mirva Lohiniva-Kerkelä, 'Ketä kuullaan - kuka päättää?: Alaikäisen osallisuus ja itsemääräämisoikeus terveyden- ja sairaanhoidossa' in Suvianna HakalehtoWainio and Liisa Nieminen (eds), Lapsioikeus murroksessa (Lakimiesliiton kustannus 2013) 292.

47 At the time, parents cannot access information on children over the age of 10 . According to a recent bulletin on the Ministry of Social Affairs and Health website, a more individual approach will be adopted in the future. Sosiaali- ja terveysministeriö, Tiedote 19.12.2018. Jatkossa huoltajat voivat asioida Omakannassa laajemmin lastensa puolesta - terveydenhuollon ammattihenkilöiden arvioitava lapsen kypsyys päättää omasta hoidostaan. Available at <https://stm.fi/artikkeli/-/asset_publisher/jatkossa-huoltajat-voivat-asioidaomakannassa-laajemmin-lastensa-puolesta-terveydenhuollon-ammattihenkiloidenarvioitava-lapsen-kypsyys-paattaa-omasta $>$ accessed 31 January 2019. As an example on the discussion see also a recent interview in a Finnish journal for medical professionals by Mari Heikkilä, 'Milloin yli 1o-vuotiaan tiedot näkee Kannasta?' (2018) 38 Suomen Lääkärilehti 2062.

48 Eduskunnan oikeusasiamies 11.6.2015 Dnro 5294/2/13.

49 Etu- ja sukunimilaki (946/2017) section 44 subsection 2. Consent is not needed, for instance, if the child is unable to express his or her will. Uskonnonvapauslaki (453/2003) section 3 subsection 3 . 


\section{On Children's Participatory Rights in Court Proceedings}

In order to understand the Finnish approach to children's participation in court proceedings that concern them, it is helpful to make a distinction between different aspects of procedural participation that are acknowledged in the legislation. These aspects can broadly be divided in formal and personal participation. In formal participation, the rights to conduct proceedings as a party ('party rights') are central. Here, one can further distinguish between children's own rights to conduct proceedings and their formal procedural representation by adults, either by near relatives or other persons appointed to the task. In the personal aspect of participation, the focus is on children's oral hearings or other discussions with them, either directly with the decisionmaker or indirectly with someone else, for instance a social worker. ${ }^{51}$

In the following, children's participation in court proceedings is discussed in light of three aspects:

- Children's separate, independent exercise of party rights,

- Children's procedural representation by adults, and

- Hearing children in person.

Some examples of each of these aspects will be given in light of the Finnish legislation, discussing how they relate to the constitutional and international standards on participation and how they may affect children's actual possibilities to participate. The main focus is in proceedings that concern children's family relations, such as parental responsibility and child protection.

\subsection{Independent Exercise of Party Rights}

Children may independently exercise procedural right to be heard (puhevalta, talerätt) in court and administrative proceedings that concern their person. There are age limitations for these rights. In civil, administrative or criminal

$5^{1} \quad$ As a third, separate aspect it is possible to distinguish children's right to determine the material outcome of certain proceedings, which was discussed above. I have more thoroughly discussed these aspects in light of Finnish parental responsibility and child protection proceedings in Hannele Tolonen, Lapsi, perhe ja tuomioistuin: Lapsen prosessuaalinen asema huolto- ja huostaanotto-oikeudenkäynneissä (Suomalainen Lakimiesyhdistys 2015) 36, 122 and 26o. On a more general take on children's participation in light of the Finnish legislation, see Pajulammi (n 17) 144, where the concept of participation is seen to encompass the procedural right to be heard (puhevalta), formal and informal hearing the child, finding out the opinion of the child, giving the child an opportunity to present his or her views, and taking the views into account. In light of public law, see Mäntylä (n 28) 23, where the right to appeal to the court is also discussed among the aspects of participation. 
proceedings, children who have turned 15 years have a right to be formally heard by courts, when they are parties in proceedings. ${ }^{52}$ In child protection proceedings, this right begins at 12 years. ${ }^{53}$ In cases that do not concern children's person - for example, in matters that concern their property - the right to independently exercise party rights begins as a rule at the age of 18 .

In civil law cases, parties generally are the plaintiff and the defendant, who is named in the application for a summons. Many family proceedings are initiated by a written application instead of an application for a summons. In the legislation, it is precised who can bring such an application to the court and who is to be heard as a participant in the case (kuultava). ${ }^{54}$ In criminal law cases, the private parties are the defendant and the injured parties. Criminal responsibility starts at the age of $15 .{ }^{55}$

It is important to note that these age limitations concern a formal, 'procedural' aspect of participation. Generally, the persons who exercise party rights are served the documents of the case and given a chance to comment them in writing. They may be able to initiate proceedings and instruct a lawyer. The possibility of an oral hearing depends on the general procedural rules, which will be discussed soon.

In proceedings that concern parental responsibility, children are not considered to have a standing as a party. In the Custody Act, children are not mentioned among the applicants or the parties that are formally heard on an application. According to the preparatory works, such a role would not be in accordance with their best interests. ${ }^{56}$

$5^{2}$ On civil and criminal proceedings, see Code of Judicial Procedure, chapter 12 section 1, subsection 2 (oikeudenkäymiskaari). An unofficial translation is available at $<$ https:// www.finlex.fi/en/laki/kaannokset/1734/en17340004_20150732.pdf> accessed 11 February 2019. On administrative proceedings, see Administrative Judicial Proceedings Act, section 18, subsection 3 (hallintolainkäyttölaki). A similar provision is in a newly approved Act on Administrative Judicial Proceedings (laki oikeudenkäynnistä hallintoasioissa 808/2019), section 25, subsection 2. The Act will come to force in 2020.

53 Child Welfare Act, section 21. An unofficial translation is at <https://www.finlex.fi/fi/laki/ kaannokset/2007/en20070417.pdf> accessed 11 February 2019.

54 These hakemusasiat have been translated as 'non-contentious civil cases', but they may be contested by the participants. The provisions on these proceedings are in the Code of Judicial Procedure (768/2002) chapter 8. See also Dan Frände and others, Prosessioikeus (Alma Talent 2017) 420 (Juha Lappalainen and Tuomas Hupli).

55 In more detail, see Frände and others (n 54) 432-433 (Dan Frände) and 448 (Jaakko Rautio).

56 Hallituksen esitys eduskunnalle laeiksi lapsen huollosta ja tapaamisoikeudesta ja holhouslain muuttamisesta ja niihin liittyvien lakien muuttamisesta (HE 224/1982) 6. 
These standpoints were tested in a Supreme Court case from 2012, where a child of 16 years requested a change on parental responsibility after she had moved from one parent to another. All the court instances stated that she could not initiate the proceedings in light of the Custody Act. The child argued that the provision was in conflict with the Constitution, ECHR and CRC. The Supreme Court disagreed, referring to the preparatory works for the constitutional reform, where exercise of children's rights by others (puhevallan käyttö) was mentioned. ${ }^{57}$ According to the Court, there was no conflict with ECHR article 6, as the purpose of the Custody Act was to ensure the best interests of children, nor with CRC article 12, which leaves room for domestic legislation. It was also stated that the CECR does not apply in parental responsibility proceedings. ${ }^{58}$

In the domestic literature, the case has been discussed in light of the best interests principle, CRC, Constitution and ECHR articles 6 and $8 .{ }^{59}$ In the preparatory works of a recent reform of the Custody Act, a reference is made to the case, stating that this standpoint is not to change. ${ }^{60}$

\subsection{Procedural Representation by Adults}

Another aspect of procedural participation is children's procedural representation, where their rights in proceedings are exercised by adults. As a rule, a child who has a standing as party in judicial proceedings has to be represented until the age of 18. Generally, this task falls to the holders of parental authority ${ }^{61}$ Children who are old enough to exercise party rights act independently from their representatives. In 2016, the Supreme Court stated in a criminal case that

57 HE 309/1993 (n 17).

58 кко 2012:95. On ECtHR case law, the Supreme Court referred to Giusto, Bornacin and V.v Italy App no 38972/o6 (ECtHR, 15 May 2007). In the case, the relationship between the adults and a 1o-year-old child was not considered to form family life in the meaning of article 8 .

59 On these viewpoints, see Sanna Koulu, Lapsen huolto ja tapaamissopimukset: Oikeuden rakenteet ja sopivat perheet (Lakimiesliiton kustannus 2014) 269; Pajulammi (n 17) 389; Tolonen (n 51 ) 255 .

6o HE 88/2018 (n 37) 59.

61 On personal matters, see Custody Act, section 4, subsection 3 (From 1 December 2019, subsection 4). In economic matters, children are represented by their guardians (edunvalvoja), but generally the holders of parental authority also act as guardians. Guardianship Services Act 442/1999 (laki holhoustoimesta) section 4, subsection 1. An unofficial translation can be found at <https://www.finlex.fi/fi/laki/kaannokset/1999/en19990442.pdf> accessed 11 February 2019. In some types of family proceedings, for example, concerning parental responsibility and paternity, social authorities may also initiate and conduct proceedings. 
an opposing opinion of a 15-year-old child did not prevent his representative from making claims on his behalf. ${ }^{62}$

The general legislative framework for representation is set in the Guardianship Services Act. According to its provisions, a substitute guardian (edunvalvojan sijainen) may be appointed, for example, if the guardian has a standing in a matter or there is a conflict of the interests for another reason. ${ }^{63}$ If interests conflict, a court handling a case may also appoint a guardian for the purposes of the proceedings. ${ }^{64}$

The Guardianship Services Act mainly concerns economic matters. ${ }^{65}$ In the matters that concern children's person, the provisions on representation have been vaguer and varying. ${ }^{66}$ If either or both of the holders of parental authority have a standing as a party in the proceedings, substitute representation in some situations - but not always - is required. In a recent legislative reform, general provisions on substitute representation in personal matters were added to the Custody Act. According to the provision, a representative (edunvalvoja) may be appointed, for instance, if there is a conflict of interest between the holder of parental responsibility and the child. In addition, it is required that the appointment is needed to ensure the investigation of the case or the child's best interests. 67

In some fields, there are specific provisions on children's substitute representation. In child protection proceedings, a representative (edunvalvoja) has to be appointed if the holders of parental responsibility cannot impartially represent the interests of the child and this is needed to ensure the investigation of the case or the child's best interests. ${ }^{68} \mathrm{~A}$ broadly similar provision applies in criminal proceedings, where a representative (edunvalvoja) may be appointed to an injured underage party during the investigation and continue in the task during an eventual trial. ${ }^{69}$

62 KКО 2016:24.

63 Guardianship Services Act, section 32 (649/2007) and section 11. See also Pertti Välimäki, Edunvalvontaoikeus (Alma Talent 2013) 98-102.

64 Code of Judicial Procedure, chapter 12 section 4a; Administrative Judicial Procedure Act, section 19 .

65 See Guardianship Services Act, section 29.

66 See also Välimäki (n 63) 251.

67 Custody Act (190/2019) section 5c.

68 Child Welfare Act, section 22. In the unofficial translation (n 53), 'a guardian to deputise for a custodian'.

69 Criminal Investigation Act 805/2011 (esitutkintalaki) chapter 4 section 8. In the unofficial translation, the word 'trustee' is used <https://www.finlex.fi/en/laki/kaannokset/ 2011/en20110805_20150736.pdf> accessed 11 February 2019. Examples on such provisions can also be found in social welfare, paternity, and adoption legislation. 
The role of these representatives (edunvalvoja) is to ensure the interests of the child. When one is appointed, it seems that the task is often entrusted to a lawyer. ${ }^{70}$ A separate role in judicial proceedings is a legal advisor (oikeudenkäyntiavustaja), which a party may also have. Legal advisors take instructions from their clients. ${ }^{71}$ In practice, it may be that neither is appointed. ${ }^{72}$

In the matters concerning parental responsibility, attitudes towards children's representation have traditionally been wary, motivated by their lack of formal standing as a party. ${ }^{73}$ In the Supreme Court case that was discussed above, the teenager who was attempting to start the proceedings also requested for an appointment of a representative (edunvalvoja). The request was not granted. Instead, the Supreme Court stated that such an appointment may be made in child protection cases. ${ }^{74}$

The recent reform of the Custody Act does not aim to change this. On parental responsibility proceedings, it is specifically stated in the preparatory works that a child is not a party nor may a representative (edunvalvoja) be appointed for the proceedings. Children's opinions will be primarily assessed by social authorities, who may also be heard in the court. ${ }^{75}$

Here, ECtHR has taken an interestingly differing approach, emphasising the quality of children's procedural representation in a fairly recent case that concerned parental responsibility. In the case of $N$. Ts. and others $v$ Georgia (2016),

70 On observation in child protection proceedings see Virve-Maria de Godzinsky, Huostaanottoasiat hallinto-oikeuksissa: Tutkimus tahdonvastaisten huostaanottojen päätöksentekomenettelystä (Oikeuspoliittinen tutkimuslaitos 2012) 102-103. On observation in criminal investigations see Hannele Tolonen, 'Kuka asiani omistaa? Alaikäinen läheisasianomistaja ja oikeus kieltäytyä todistamasta' in Juhana Riekkinen (ed), Oikeutta oikeudenkäynnistä täytäntöönpanoon: Juhlajulkaisu Tuula Linna 1957 -25/9 - 2017 (Alma Talent 2017) 395, 399.

71 On attorneys and counsels see Code of Judicial Procedure chapter 15 . In child protection proceedings, the court may appoint a legal advisor for the child on request or its own accord. Child Welfare Act, section 87. On criminal proceedings, it has been discussed whether the same person may act as a representative and a legal advisor for the child. See Välimäki (n 63) 257-259, where this is generally seen acceptable.

72 See, for example, Supreme Administrative Court case KHO 2018:159 on child protection, where a disabled teenager was represented by the holders of parental responsibility.

73 See, for instance, HE 88/2018 (n 37) 61. However, children may be appointed representatives in adoption proceedings, although they are not among the persons who may initiate the proceedings in the district court or who are to be formally heard. Adoption Act 22/ 2012 (adoptiolaki) sections 51, 54, and 55.

74 KКО 2012:95 (n 58$)$.

75 Custody Act (190/2019) sections 16 and 16a; HE 88/2018 (n 37) 61-64. An expert may be appointed to help the judge in a child's hearing. Section 15 a subsection 2 (190/2019). 
a breach of children's article 8 rights was found, as their representation was considered flawed and their views not duly heard or presented.

In the domestic proceedings, the father had requested the return of three sons, who had stayed with the relatives of their deceased mother. The request was granted, but the decision was not enforced, because the children refused to move in with their father. The case was brought to ECtHR by the boys' aunt.

In the case, the domestic court had instructed the social authorities to appoint a representative. This arrangement was not considered to constitute adequate and meaningful representation. ECtHR criticised especially the lack of a regular contact with the children and the lack of formal procedural role. According to the description of the case, the representatives drafted reports and attended court hearings in the appeal stage as an 'interested party', meeting the children only a few times. This was not considered sufficient. ${ }^{76}$

In the case, ECtHR assessed the standards for children's representation in light of the CECR, although Georgia had not ratified the convention. A reference was also made to the Guidelines on child-friendly justice. ${ }^{77}$ From the perspective of Finnish parental responsibility proceedings, it is interesting to note that the CECR was interpreted to set the international standard for children's representation notwithstanding the domestic ratification. It will be interesting to see how the case law on children's participation develops in the future.

\subsection{Hearing Children in Person}

An important aspect of children's procedural participation is the question on hearing them in person. In the Finnish system, personal hearing may take place in several different contexts.

Firstly, an opportunity for a direct contact with the members of the court may arise when a child is old enough to exercise party rights in a case where an oral hearing is arranged. Generally, oral hearings are a rule in the provisions

$76 \quad$ N. Ts. and others $v$ Georgia App no 71776/12 (ECtHR, 2 February 2016) paras 74-77. On the older case law, see Nanning $v$ Germany App no 39741/o2 (ECtHR, 12 July 2007), where a breach of a parent's article 8 rights was found in a contact case. Among other factors, an observation was made on the lack of a teenager's independent representation (para 75).

77 On these, see Council or Europe, Guidelines of the Committee of Ministers of the Council of Europe on child-friendly justice (Council of Europe 2011). 
on criminal proceedings and contested civil proceedings. ${ }^{78}$ In administrative court proceedings, where, for example, child protection cases belong, the provisions on oral hearings are more flexible. Even if a party requests an oral hearing, the provisions leave the court some discretion. ${ }^{79}$

Secondly, children may personally participate in oral hearings by giving evidence in the case. It is possible - although restricted by age - that a child is heard as a witness or gives evidence as a party. According to the general procedural provisions, the restrictions apply to children under the age of 15 , whose hearing is left in the court's discretion. A lower age limitation, 12 years, will apply for witnesses in administrative judicial proceedings, when a recently approved new Act comes to force. ${ }^{80}$

In addition to these direct means of participation, children's personal hearing in some proceedings may take place indirectly in other authorities - such as social authorities or police - who will then present this material to the court. The materials from these hearings or discussions may be presented in written form - as generally in proceedings on parental responsibility - or by audiovisual means, which is now the general rule in criminal investigation when hearing children who are under 15 years old. ${ }^{81}$

In the recent years, obstacles to children's direct, oral participation have been lowered in court proceedings that concern children's family relations. In the Child Welfare Act (417/2007) and its later modifications, the restrictions on children's personal involvement have been relaxed and the frame of their hearing specified. When a child is under 12, the court may refrain from personal hearing because of the possible negative consequences to child. Hearing is possible outside of the courtroom and with a limited audience. ${ }^{82}$ In a recent

78 In a contested civil case, an exception may be made in light of the nature of the case, if none of the parties oppose. Code of Judicial Procedure, chapter 5 section $27 \mathrm{a}(768 / 2002)$. On criminal cases the prerequisites for deciding the case on basis of written material are set in the Criminal Procedure Act, chapter 5 a section 1 (243/2006). An unofficial translation is available at $<$ https://www.finlex.fi/en/laki/kaannokset/1997/en1997o689_ 20150733.pdf> accessed 11 February 2019. On these provisions, see also Frände and others (n 54) 1018 (Juha Lappalainen and Tuomas Hupli) and 1383 (Dan Frände).

79 Administrative Judicial Procedure Act, sections 37 and 38. In the recently approved Act on administrative judicial proceedings $\left(808 / 2019, \mathrm{n}_{52}\right.$ ), the provisions on oral hearing are more detailed but allow discretion.

80 On the recently approved Act (808/2019), see $\mathrm{n} 52$. On the general procedural provisions, see Code of Judicial Procedure, chapter 17 (732/2015) sections 27 and 30 . Hearing has to be of essential significance and the child's development should not be harmed. A support person may also be appointed. On the current similar legislation on witnesses in administrative court proceedings, see Administrative Judicial Procedure Act, section 39 f.

81 Code of Judicial Procedure, chapter 17 (732/2015) section 24, subsection 3.

82 Child Welfare Act (88/2010) section 86. 
reform, similar provisions were adopted in the Custody Act, where the restrictions traditionally have applied to all children to protect them from the conflict between parents. ${ }^{83}$ This is a considerable change, arguably towards the direction of the developing international standards.

Easing restrictions on children's personal participation in family proceedings finds support in recent Strasbourg case law. Traditionally, the requirements on children's participation have not been very strict. ${ }^{84}$ Instead, ECtHR has focused on adults and their participatory rights. ${ }^{85}$ In the recent case law, children's own procedural rights have been examined and found lacking.

Assessing participation in light of the importance of the case to the child is visible in M. and M. $v$ Croatia (2015), where ECtHR found a breach of a 13-year-old child's article 8 rights in a parental responsibility case, stating that the seriousness and urgency of the situation was not recognised by the domestic courts. It was particularly noted that the child, who was 9 years old when the proceedings began, had not been given a chance to be heard in the proceedings. ${ }^{86}$ In N. Ts. and others $v$ Georgia (2016), the ECtHR criticised the domestic courts for not considering the possibility of directly involving the oldest child and not giving reasons for not hearing him. The proceedings had begun when the child was about 7 years old and lasted about two years. ${ }^{87}$

From these cases, one can read a narrower view of restrictions to children's rights to procedural participation, in comparison to the earlier case law. ${ }^{88}$ This calls for attention at the national level. However, it should be noted that the requirements are not identical to those on adults' participation. In M. and M., the Court notes that children's autonomy is exercised through the right to be consulted and heard. ${ }^{89}$ In Blokhin v Russia (2016), the Grand Chamber stated

83 Custody Act (190/2019) section 15a. See also HE 88/2018 (n 37). On the earlier restrictions see Custody Act (361/1983) section 15 subsection 2.

84 See also Shazia Choudhry and Jonathan Herring, European Human Rights and Family Law (Hart Publishing 2010) 239, where for example Sahin v Germany App no 30943/96 (ECtHR, Grand Chamber 8 July 2003) is discussed.

85 See also Fortin (n 43) 238-239.

86 M. and M. v. Croatia (n 27) paras 182-187. In the case, parental proceedings were intertwined with criminal investigation against one of the parents.

$87 \quad N$. Ts. and others $v$ Georgia ( $\mathrm{n} 76$ ) para 8 o. The domestic legislation required hearing children over the age of seven.

88 On the earlier case law where children's personal hearing was not required in light of a parent's article 8 rights, see Sahin v Germany (n 84) and Kajariv Finland App no 65040/ o1 (ECtHR, 23 October 2007).

$89 \quad$ M. and M. v Croatia (n 27) para 171. See also N. Ts. and others (n 76$)$ para 72. 
that children may need additional procedural safeguards and that their rights should be secured in adapted, age-appropriate setting. ${ }^{90}$

\section{$4 \quad$ Aspects of Participation and Actual Participation in Court Proceedings}

It is not self-evident how the aspects of participation relate to each other and how they affect children's actual possibilities to participate in individual cases that concern them. For example, it is interesting to note that children may be given a substantial input in the material decision despite their lacking standing as a party. It is not an easy task to grasp the interconnections between different aspects of participation, especially when they are interpreted in varying procedural environments.

When children's participation has been discussed in light of the provisions of the CRC, the focus has often been in the possibilities to directly address the decision-maker. In the most recent comments to Finland, the Committee on the Rights of the Child stated that age limitations on participation should be abolished in the domestic law. In the comment, provisions concerning formal, procedural participation are mentioned along those concerning other, more informal means of participation. ${ }^{91}$

However, it should be asked whether the legislative age limitations that are set in different contexts - representing different aspects of participation have a similar effect on children's participation. In the Finnish procedural reality, such an assumption may not hold. Conducting procedural party rights might not bring a chance to meet the judge, nor does a lack of such formal rights necessarily mean that there are no possibilities for participation. Even if children do not independently conduct formal procedural rights, other means of participation may be available: direct or indirect, or possibly both. On the other hand, an older child who is 'heard' as a party in proceedings that concern his or her person may not necessarily attend an oral hearing.

Children's constitutional right to participate, CRC article 12 and the earlier critical comments from the Committee on the Rights of the Child were discussed by the Constitutional Law Committee of the Parliament when assessing

$90 \quad$ Blokhin v Russia (n 23) paras 219-220.

$91 \mathrm{CRC/C/FIN/CO/4} \mathrm{(n} \mathrm{4)} \mathrm{paras} \mathrm{29-30.} \mathrm{See} \mathrm{Pajulammi} \mathrm{(n} \mathrm{17)} \mathrm{154;} \mathrm{Tolonen} \mathrm{(n} \mathrm{51)} 133$. On the critique of age limitations, see Suvianna Hakalehto-Wainio, 'Lapsen oikeudet ja lapsen etu lapsen oikeuksien sopimuksessa' in Suvianna Hakalehto-Wainio and Liisa Nieminen (eds), Lapsioikeus murroksessa (Lakimiesliiton Kustannus 2013) 17, 41. 
the proposed rules for children's participation in the Child Welfare Act (417/ 2007). As a conclusion, the age limitations on conducting procedural rights and oral hearing were set to 12 years, lower than was proposed. ${ }^{92}$

In the recent years, children's participation in child protection proceedings has become a popular topic of study. In several reports, it has been observed that having a legal advisor is in many cases linked to a stronger presence in administrative court proceedings on taking children in public care. ${ }^{93}$ For a child, having support from adult parties may also be important. According to a qualitative study by the author of this article, older children who disagreed with the holders of parental responsibility, being 'against the rest of the world' in their opinion, generally contributed little to the proceedings despite having a formal role..$^{94}$

From the observations in child protection cases, it seems that children over 12 have more visibility in the proceedings than younger children. ${ }^{95}$ Despite this, it can be asked whether abolishing or lowering the age when children start conducting independent party rights is the most appropriate measure to advance their possibilities to participate. It is doubtful whether very young children would benefit from being served the case documents. It is problematic if the age limit determines participation so that the younger children are left out, but by merely giving them formal party rights, the problem may be far from solved.

When the case material is delicate, questions on protecting children also arise. According to the Child Welfare Act, children who are heard in courts may not be given information that could seriously damage their health or development. ${ }^{96}$ The Constitutional Law Committee of the Parliament assessed the provision in light of the Constitution and CRC article 12, finding it acceptable in light of children's best interests and their protection. ${ }^{97}$ If all age limitations for children's independent procedural conduct were removed, much more

92 PeVL $58 / 2006$ (n 14 ) 6-7. In the proposal, the age of 15 was suggested for some measures.

93 On such observations on families' and/or children's legal advisors see Johanna Hiitola and Hanna Heinonen, Huostaanotto ja oikeudellinen päätöksenteko: Hallinto-oikeuksien ratkaisut huostaanottoasioissa (Terveyden ja hyvinvoinnin laitos 2009) 39; de Godzinsky (n 70 ) 78, 88; Tolonen (n 51) 277 .

94 Tolonen (n $\left.5^{1}\right)$ 270. The observation was made from case material that had been collected in one Finnish administrative court.

95 de Godzinsky (n 70) 138; Tolonen (n 51) 274.

96 Child Welfare Act, section 86, subsection 1 (88/2010).

97 Perustuslakivaliokunnan lausunto hallituksen esityksestä laeiksi lastensuojelulain, vankeuslain 4 ja 20 luvun sekä tutkintavankeuslain 2 luvun 5 §:n muuttamisesta (PeVL 30/2009) 3-4. 
consideration should be given to the suitability of the material. In practice, alternative means of arranging young children's participation would be needed in addition - or instead - the right to formally conduct the proceedings. The need for alternative, child-friendly proceedings has also been emphasised by the Committee on the Rights of the Child. ${ }^{98}$

Another concern is that giving children a right to conduct procedural rights may place a part of the responsibility on the manner of participation on their own shoulders, especially when arranging an oral hearing depends on the parties' requests or statements. It can be difficult for a child to effectively take part in this conversation. The Finnish word for having a standing in the proceedings - puhevalta - can literally be translated as 'power of speech'. Without adequate help, having this power may not amount to much. Support and information throughout the process may be needed to ensure a real opportunity to participate, despite the presence - or the lack - of formal party rights, i.e. legal standing. This idea is expressed in the international instruments. Personal, individual aspects have also been emphasised in the recent ECtHR case law, as is demonstrated in the cases of $N$. Ts. and others and Blokhin. ${ }^{99}$

Logically, providing children with more effective means of participation in light of the circumstances of the case has become more central when discussing their representation. As mentioned above, specific provisions on individual assessment of representation apply, for example, in child protection proceedings. Currently, these provisions allow for wide discretion, even when the matter concerns older children or children who stand alone in their opinion. According to observations on taking children in public care, children do not generally have substitute representation or legal assistance in court proceedings. ${ }^{100}$ It has been argued that such measures are needed in more cases. ${ }^{101}$ Despite the right to receive documents, even teenagers may have problems with understanding or responding accordingly. They should receive help from the social authorities and in the institutions where they are placed. In practice, little information on this help may reach the court. ${ }^{102}$ In parental responsibility proceedings, no provisions on children's representation currently

\footnotetext{
$98 \mathrm{CRC} / \mathrm{C} / \mathrm{FIN} / \mathrm{CO} / 4$ (n 4) para 3 o.

99 Blokhin v Russia (n 23) para 206; N. Ts. and others v Georgia $\left(\mathrm{n}_{7} 6\right)$ para 75 . See also CECR article 10.

100 de Godzinsky (n 7o) 101-103; Tolonen (n 51) 274-275 and 365-366.

101 Ibid. See also Virve-Maria Toivonen (de Godzinsky), Lapsen oikeudet ja oikeusturva: Lastensuojeluasiat hallintotuomioistuimissa (Alma Talent 2017) 152-154.

102 Tolonen ( $_{51}$ ) 268. The importance of giving information to children is visible for example in CECR article 3. On information in child protection proceedings see also Toivonen (n 101) 16o-161.
} 
apply. In $N$. Ts. and others, the flaws in representation were a central factor when assessing children's article 8 rights. ${ }^{103}$ Despite differences between the national systems, the developing international standards call for a closer attention to the availability and quality of representation.

These cases also remind the domestic interpreters that it is necessary to look at the proceedings at hand and the system of participation as a whole instead of concentrating in one aspect of participation. This approach is visible in $N$. Ts. and others, where procedural representation and personal participation are observed and discussed in relation to each other. ${ }^{104}$ More research is needed on children's procedural participation and its possible obstacles in different proceedings.

In legislation and every step of interpretation, the child's perspective of the procedural reality should be the primary consideration. An example of an individual approach can be found in Blokhin, where the Grand Chamber of the ECtHR gives a detailed analysis on the child's specific circumstances, discussing how he must have felt in the unfamiliar situation. ${ }^{105}$

\section{5}

\section{Conclusions}

In the older discussion on children's participation, the focus was mainly on two areas: material decision-making capacity and formal procedural representation. The latter aspect was voiced in the preparatory works for the constitutional provision on children's participation, which has been interpreted to de-emphasise children's personal role. In the later legislative work and literature, a stronger accentuation on children's own, actual possibilities for procedural participation can be seen to emerge, mirroring the international development in the field. In recent case law, ECtHR has emphasised individual assessment of participation, quality of representation and acknowledging the special needs of children. It is interesting to see how the international standards will develop and how they affect the understanding of participatory rights in the future.

\footnotetext{
$103 \quad$ N. Ts. and others $v$ Georgia $\left(\mathrm{n}_{7} 6\right)$ paras 77 and 84.

104 N. Ts. and others $v$ Georgia ( $\mathrm{n} 76)$ paras 80 and 84.

105 Blokhin v Russia (n 23) para 208: '... the Court considers that the applicant must have felt intimidated and exposed while being held alone at the police station and questioned in an unfamiliar environment'. The case is discussed with regard to Finnish child protection proceedings in Hannele Tolonen, 'Lapsi, rikos ja suojelu: Oikeudenkäynnille asetettavista vaatimuksista EIT:n uuden ratkaisukäytännön valossa' in Suvianna Hakalehto and Virve Toivonen (eds), Lapsen oikeudet lastensuojelussa (Kauppakamari 2016) 342.
} 
Despite the emphasis on children's participation in recent legislation, there is considerable variation between different fields, for example, in the legal framework on formal and personal aspects of procedural participation. The variation in general procedural provisions may lead to different outcomes in participation even when the provisions on participation seem similar. Attention to proceedings as a whole and to interpretations at different levels is needed to assess how the opportunities for participation appear from children's perspective.

\section{References}

Berrick JD and others, 'International Perspectives on Child-responsive Courts' (2018) 26(2) Int J of Children's Rights 251.

Choudhry S and Herring J, European Human Rights and Family Law (Hart Publishing 2010).

Council of Europe, Guidelines of the Committee of Ministers of the Council of Europe on child-friendly justice (Council of Europe 2011).

Couzens M, 'Child Participation in Local Governance' in Martin D. Ruck, Michele Peterson-Badali, and Michael Freeman (eds), Handbook on Children's Rights: Global and Multidisciplinary Perspectives (Routledge 2017).

Fortin J, Children's Rights and the Developing Law (3rd edn, Cambridge University Press 2009).

Frände D and others, Prosessioikeus (Alma Talent 2017).

de Godzinsky V, Huostaanottoasiat hallinto-oikeuksissa: Tutkimus tahdonvastaisten huostaanottojen päätöksentekomenettelystä (Oikeuspoliittinen tutkimuslaitos 2012).

Gottberg E, 'Lapsen subjektiudesta ja osallisuudesta huoltokysymyksissä ja lastensuojelussa' (2008) 3 Defensor Legis 319.

Hallituksen esitys eduskunnalle kuntalaiksi ja eräiksi siihen liittyviksi laeiksi (HE 268/ 2014).

Hallituksen esitys eduskunnalle laiksi lapsen huollosta ja tapaamisoikeudesta annetun lain muuttamisesta ja eräiksi siihen liittyviksi laeiksi (HE 88/2018).

Hallituksen esitys eduskunnalle perustuslakien perusoikeussäännösten muuttamisesta (HE 309/1993).

Hallituksen esitys eduskunnalle laeiksi lapsen huollosta ja tapaamisoikeudesta ja holhouslain muuttamisesta ja niihin liittyvien lakien muuttamisesta (HE 224/1982).

Hakalehto-Wainio S, 'Lapsen oikeudet ja lapsen etu lapsen oikeuksien sopimuksessa' in Suvianna Hakalehto-Wainio and Liisa Nieminen (eds), Lapsioikeus murroksessa (Lakimiesliiton Kustannus 2013) 17. 
Helander M, 'Utvecklingsbehov i den finländska lagstiftningen om barn' (2018) 1 Nordisk Administrativt Tidsskrift 5 .

Helin M, 'Perusoikeuksilla argumentoinnista' in Tero Iire (ed), Varallisuus, vakuudet ja velkojat: Juhlajulkaisu Jarmo Tuomisto 1952 - 9/6 - 1912 (Turun yliopisto, oikeustieteellinen tiedekunta 2012) 11.

Heikkilä M, 'Milloin yli 10-vuotiaan tiedot näkee Kannasta?' (2018) 38 Suomen Lääkärilehti 2062.

Hiitola J and Heinonen H, Huostaanotto ja oikeudellinen päätöksenteko: Hallintooikeuksien ratkaisut huostaanottoasioissa (Terveyden ja hyvinvoinnin laitos 2009).

Hirvelä P and Heikkilä S, Ihmisoikeudet: Käsikirja EIT:n oikeuskäytäntöön (2 edn, Alma Talent 2017).

Koulu S, Lapsen huolto ja tapaamissopimukset: Oikeuden rakenteet ja sopivat perheet (Lakimiesliiton kustannus 2014).

Koulu S, 'Children's Right to Family Life in Finland: A Constitutional Right or a Side Effect of the "Normal Family"?' in Trude Haugli and others (eds), Children's Constitutional Rights in the Nordic Countries (Brill 2019).

Länsineva P, 'Perusoikeusliike' In Tatu Hyttinen and Katja Weckström (eds), Turun yliopiston oikeustieteellinen tiedekunta 50 vuotta (Turun yliopisto, oikeustieteellinen tiedekunta 2011) 339 .

Mäntylä N, 'Lasten ja nuorten osallistumisen oikeudelliset ongelmat' in Niina Mäntylä (ed), Lapset ja nuoret yhteiskunnan toimijoina (Vaasan yliopiston julkaisuja 2011) 21.

Nieminen L, Lasten perusoikeudet (Lakimiesliiton kustannus 199o).

Nieminen L, Perus-ja ihmisoikeudet ja perhe (Talentum 2013).

Ojanen T and Scheinin M, 'Kansainväliset ihmisoikeussopimukset ja Suomen perusoikeusjärjestelmä' in Pekka Hallberg and others, Perusoikeudet (WSOYpro 2011) 171.

Pajulammi H, Lapsi, oikeus ja osallisuus (Talentum 2014).

Parkinson P and Cashmore J, The Voice of a Child in Family Law Disputes (Oxford University Press 2008).

Pellonpää M and others, Euroopan ihmisoikeussopimus (6th edn, Alma Talent 2018).

Perustuslakivaliokunnan lausunto hallituksen esityksestä lastensuojelulaiksi ja eräiksi siihen liittyviksi laeiksi (PeVL 58/2006).

Perustuslakivaliokunnan lausunto hallituksen esityksestä laeiksi lastensuojelulain, vankeuslain 4 ja 20 luvun sekä tutkintavankeuslain 2 luvun 5 §:n muuttamisesta (PeVL 30/2009).

Perustuslakivaliokunnan mietintö n:o 25 hallituksen esityksestä perustuslakien perusoikeussäännösten muuttamisesta (PeVM 25/1994).

Pollari K and Lohiniva-Kerkelä M, 'Ketä kuullaan - kuka päättää? Alaikäisen osallisuus ja itsemääräämisoikeus terveyden- ja sairaanhoidossa' in Suvianna HakalehtoWainio and Liisa Nieminen (eds), Lapsioikeus murroksessa (Lakimiesliiton kustannus 2013) 269 . 
Savolainen M, Lapsen huolto ja tapaamisoikeus (Suomen Lakimiesliiton kustannus 1984).

Sosiaali- ja terveysministeriö, Tiedote 19.12.2018. Jatkossa huoltajat voivat asioida Omakannassa laajemmin lastensa puolesta - terveydenhuollon ammattihenkilöiden arvioitava lapsen kypsyys päättää omasta hoidostaan, available at <https://stm .fi/artikkeli/-/asset_publisher/jatkossa-huoltajat-voivat-asioida-omakannassalaajemmin-lastensa-puolesta-terveydenhuollon-ammattihenkiloiden-arvioitavalapsen-kypsyys-paattaa-omasta> accessed 31 January 2019.

Toivonen V, Lapsen oikeudet ja oikeusturva: Lastensuojeluasiat hallintotuomioistuimissa (Alma Talent 2017).

Tolonen H, 'Kuka asiani omistaa? Alaikäinen läheisasianomistaja ja oikeus kieltäytyä todistamasta' in Juhana Riekkinen (ed), Oikeutta oikeudenkäynnistä täytäntöönpanoon: Juhlajulkaisu Tuula Linna 1957 -25/9 - 2017 (Alma Talent 2017) 395.

Tolonen H, Lapsi perhe ja tuomioistuin: Lapsen prosessuaalinen asema huolto-ja huostaanotto-oikeudenkäynneissä (Suomalainen Lakimiesyhdistys 2015).

Tolonen H, 'Lapsi, rikos ja suojelu: Oikeudenkäynnille asetettavista vaatimuksista EIT:n uuden ratkaisukäytännön valossa' in Suvianna Hakalehto and Virve Toivonen (eds), Lapsen oikeudet lastensuojelussa (Kauppakamari 2016).

UN Committee on the Rights of the Child, Concluding observations: Finland (3 August 2011) $\mathrm{CRC} / \mathrm{C} / \mathrm{FIN} / \mathrm{CO} / 4$.

UN Committee on the Rights of the Child, General comment No. 12 (2009) on the right of the child to be heard (20 July 2009) CRC/C/GC/12.

Välimäki P, Edunvalvontaoikeus (Alma Talent 2013).

Viljanen V, 'Perusoikeuksien merkitys lainsäädäntötyössä’ in Pekka Hallberg and others, Perusoikeudet (WSOYpro 2011) 833.

Viljanen V, 'Yksityiselämän suoja (PL 10 §)' in Pekka Hallberg and others, Perusoikeudet (WSOYpro 2011) 389.

White RCA and Ovey C, Jacobs, White and Ovey: The European Convention on Human Rights (5th edn, Oxford University Press 2010). 